\title{
ПОНЯТТЯ КРИМІНАЛЬНИХ ПРОСТУПКІВ ТА ПИТАННЯ ЇХ КВАЛІФІКАЦІї
}

\section{АЛЕКСЕСВА-ДАНИЛЕНКО Юлія Володимирівна - аспірант Харківського національного університету внутрішніх справ}

DOI 10.32782/EP.2020.3.16

У статті розглянуті поняття та зміст кримінального проступку як категорї кримінального права, охарактеризовані ознаки за якими здійснюється квалібікація кримінальних проступків, проведений перелік статей Кримінального кодексу Украӥни, якими передбачено склад кримінальних проступків як кримінально караних діянь. Підкреслено, що запровадження кримінальних проступків у законодавство України про кримінальну відповідальність є одним із напрямів державної кримінально-правової політики, який полягає в гуманізачії кримінальної відповідальності. Показано, що кримінальні проступки займають особливе місие в кримінальному законодавстві в силу їх поширеності за кількістю та різноманітною спрямованістю на суспільні відносини.

Аргументовано, що нормативною юридичною підставою для квалібікациї протиправного діяння, як кримінального проступку, $є$ його склад, який передбачений у кримінальній нормі. Як і для злочину, для встановлення кримінального проступку $є$ загальнообов'язковими: а) суспільна небезпечність; б) кримінальна протиправність; в) винність $i$ каранність діяння.

Проблема запровадження інституту кримінальних проступків у національне законодавство залишається, попри низки публікащії, відкритою. Залишаються малодослідженими критеріі розмежування видів кримінальних проступків від злочинів, правові наслідки вчинення кримінальних проступків, протидія причинам $і$ умовам, які сприяють вчиненню проступків.
Ключові слова: кримінальний проступок, законодавство, кримінальне правопорушення, посягання, склад проступку, причинний зв'язок.

\section{Вступ}

Запровадження інституту кримінальних проступків $\epsilon$ реакцією на потребу гуманізації кримінального права шляхом перетворення окремих нетяжких злочинів на кримінальні проступки, гарантування судового захисту прав особи у справах про кримінальне обвинувачення (щодо кваліфікації майна, виправних робіт, короткострокового арешту тощо) на підставі вимог ст. 6 Конвенції про захист прав людини і основоположних свобод, реалізації вимог Конституції України про можливість конфіскації майна лише на підставі рішення суду.

Виділення 3 передбачених Кримінальним кодексом України злочинів деяких менш небезпечних діянь у групу кримінальних проступків та встановлення правових наслідків, які відрізняються за ступенем, тривалістю, характером обмежень прав та свобод правопорушника від правових наслідків вчинення особою злочину, дозволило послабити офіційно рівень криміналізації суспільства, гуманізувати законодавство у сфері протидії злочинності.

Одночасно запровадження в законодавстві кримінального проступку, як протиправного діяння, обумовило низку проблемних питань щодо їх правової кваліфі- 
кації, розмежування і з кримінальними злочинами, караності за їх вчинення.

Мета статті полягає в тому, щоб проаналізувати поняття і зміст кримінального проступку як протиправного явища, сформувати іх перелік за статтями Кримінального кодексу України та охарактеризувати ознаки юридичної класифікації кримінальних проступків.

\section{Стан наукової розробленості}

Питання впровадження кримінальних проступків до їх законодавчого визначення розглядалися в наукових роботах С.В. Ківалова (Категорія кримінальних проступків у контексті доктрин кримінального та кримінально-процесуального права - стаття, 2013 рік), Н.М. Мірошниченко (Концептуальні питання запровадження інституту кримінальних проступків у законодавстві України - стаття, 2015 рік), О.В. Сачко (Правова визначеність що до інституту кримінальних проступків та процесуальної форми дізнання - стаття, 2018 р.), Д.С. Азарова (Упровадження категорії кримінального проступку: окремі концептуальні проблеми - стаття, 2013 р.), Романа Оксанича (Інститут кримінальних проступків зелене світло? - стаття, 2018 р.), А.С. Макаренко (Теоретичні основи пеналізаціі кримінальних проступків - стаття, 2014 р.), В.І. Борисова, В.І. Тютюгіна, А.М. Демидовоі (Кримінальний проступок: концептуальні засади запровадження до національного законодавства - стаття, 2016 р.) та інші автори.

Aле після запровадження законодавства про кримінальні проступки в дію у 2020 році, тема кримінальних проступків не знайшла достатнього висвітлення в юридичній літературі. Постає нагальна потребність і доцільність розглянути поняття кримінальних проступків та підстави їх класифікації вже з урахуванням їх кримінально-правового визначення.

\section{Виклад основного матеріалу}

Закон України «Про внесення змін до деяких законодавчих актів України щодо спрощення досудового розслідування окре- мих категорій кримінальних правопорушень» набув чинності 1 липня 2020 року. ${ }^{1}$

Змінами до статті 11 Кримінального кодексу України введено поняття «кримінального правопорушення», яке узагальнює всі види кримінальних посягань (злочинів і кримінальних проступків) як «суспільно небезпечне винне діяння (дія або бездіяльність), вчинене суб’єктом кримінального правопорушення ${ }^{2}$.

Надання чинності кримінальним проступкам обумовило низку проблемних питань кримінально-правового та кримінально-процесуального характеру, які потребують свого теоретичного і практичного розв'язання. Кримінальний проступок $\epsilon$ різновидом кримінального правопорушення, за вчинення якого передбачається кримінальна відповідальність.

Кримінальний проступок, як протиправне кримінальне явище, був встановлений ще в Кримінальному процесуальному кодексі України, прийнятому 13 квітня 2012 року та набрав чинності 20 листопада 2012 року.

Як бачимо, пройшло вісім років до того, як кримінальний проступок у правовому визначенні став реальністю.

Законом визначено, що кримінальним проступком $є$ діяння ( дія чи бездіяльність), за вчинення якого передбачено покарання у виді штрафу в розмірі не більше трьох тисяч неоподаткованих мінімумів доходів громадян, або інше покарання, не пов'язане з позбавленням волі.

Кримінальні проступки, як протиправні діяння, тягнуть за собою настання певних негативних наслідків, які проявляються в порушенні прав іншої фізичної чи юридичної особи, завдання їм матеріальної чи моральної шкоди.

У ст. 12 Кримінального кодексу України встановлено види кримінальних правопорушень (кримінальні злочини та кримі-

\footnotetext{
1 Закон України «Про внесення змін до деяких законодавчих актів України щодо спрощення досудового розслідування окремих категорій кримінальних правопорушень»//Відомості Верховної Ради України, 2017. - № 17, С. 71.

${ }^{2}$ Кримінальний кодекс України//Відомості Верховної Ради України, 2001. - № 25-26, С. 131.
} 


\section{Кримінальне право, кримінальний процес та криміналістика}

нальні проступки) та надано їм визначення. Кримінальні проступки виділені за рахунок злочинів невеликої тяжкості.

Кримінальні проступки відмежовується від злочинів видом та мірою покарання.

Досудове розслідування за фактами кримінальних проступків буде проводитись за спрощеною процедурою у формі дізнання і обмежується в часі. За аналізом змін до Кримінального кодексу України, проведеного автором, кримінальні проступки передбачені в 117 частинах 98 статей Кримінального кодексу України, а саме:

1 - умисне легке тілесне ушкодження (ч. 1, 2 ст.125 КК України);

2 - побої та мордування (тільки ч.1 ст.126 КК України);

3 - погроза вбивством (тільки ч.1 ст.129 КК України);

4 - розголошення відомостей про проведення медичного огляду на виявлення зараження вірусом імунодефіциту людини чи іншої невиліковної інфекційної хвороби (ст.132 КК України);

5 - примушування до стерилізації без добровільної згоди потерпілої особи (ч.4 ст.134 КК України);

6 - ненадання допомоги хворому медичним працівником (тільки ч.1 ст.139 КК України);

7 - насильницьке донорство (тільки ч.1 ст.144 КК України);

8 - незаконне розголошення лікарської таємниці (ст.145 КК України);

9 - експлуатація дітей (тільки ч.1 ст.150 КК України);

10 - примушування до вступу в статевий зв'язок (тільки ч. 1, 2 ст.154 КК України);

11 - порушення таємниці голосування (тільки ч.1 ст.159 КК України);

12 - підкуп виборця, учасника референдуму (тільки ч.1 ст.160 КК України);

13 - порушення недоторканості житла (тільки ч.1 ст.162 КК України);

14 - порушення таємниці листування, телефонних розмов, телеграфної чи іншої кореспонденції, що передаються засобами зв'язку або через комп'ютер (тільки ч.1 ст.163 КК України);

15 - ухилення від сплати аліментів на утримання дітей (ст.164 КК України);
16 - ухилення від сплати коштів на утримання непрацездатних батьків (ст.165 КК України);

17 - розголошення таємниці усиновлення (удочеріння) (тільки ч.1 ст.168 КК України);

18 - перешкоджання законній професійній діяльності журналістів (ст.171 КК України);

19 - грубе порушення законодавства про працю (тільки ч.1 ст.172 КК України);

20 - грубе порушення угоди про працю (ст.173 КК України);

21 - примушування до участі у страйку або перешкоджання участі у страйку (ст.174 КК України);

22 - невиплата заробітної плати, стипендії, пенсії чи інших установлених законом виплат (ст.175 КК України);

23 - порушення недоторканності приватного життя (тільки ч.1 ст.182 КК України);

24 - порушення права на отримання освіти (тільки ч. 1 ст.183 КК України);

25 - порушення права на безоплатну медичну допомогу (ст.184 КК України);

26 - крадіжка (тільки ч.1 ст.185 КК України);

27 - викрадення води, електричної або теплової енергії шляхом іï самовільного використання (тільки ч.1 ст.188-1 КК України);

28 - шахрайство (тільки ч.1 ст.190 КК України);

29 - заподіяння майнової шкоди шляхом обману або зловживання довірою (ст.192 КК України);

30 - незаконне привласнення особою знайденого або чужого майна, що випадково опинилося у неї (ст.193 КК України);

31 - погроза знищення майна (ст.195 КК України);

32 - самовільне зайняття земельної ділянки та самовільне будівництво (тільки ч. 1 ст.197-1 КК України);

33 - умисне порушення вимог законодавства про запобігання та протидію легалізації (відмиванню) доходів, одержаних злочинним шляхом, фінансуванню тероризму та фінансуванню розповсюдження 
зброї масового знищення (тільки ч. 1 ст.2091 КК України);

34 - порушення порядку здійснення операцій з металобрухтом (тільки ч.1 ст.213 КК України);

35 - розголошення комерційної або банківської таємниці (ст.232 КК України);

36 - незаконне заволодіння грунтовим покривом (поверхневим шаром) земель (тільки ч.1 ст.239-1 КК України);

37 - незаконне заволодіння землями водного фонду в особливо великих розмірах (тільки ч.1 ст.239-2 КК України);

38 - порушення законодавства про континентальний шельф України (тільки ч.2 ст.244 КК України);

39 - порушення законодавства про захист рослин (ст.247 КК України);

- незаконне полювання (тільки ч.1 ст.248 КК України);

40 - незаконне зайняття рибним, звіриним або іншим водним добувним промислом (тільки ч.1 ст.249 КК України);

41 - умисне знищення або пошкодження територій, взятих під охорону держави, та об'єктів природно-заповідного фонду (тільки ч.1 ст.252 КК України);

42 - проєктування чи експлуатація споруд без систем захисту довкілля (тільки ч.1 ст.252 КК України);

43 - безгосподарське використання земель (тільки ч. 1 ст.254 КК України);

44 - незаконне ввезення на територію України відходів і вторинної сировини (тільки ч.1 ст.268 КК України);

45 - порушення вимог законодавства про охорону праці (тільки ч.1 ст.271 КК України);

46 - порушення правил безпеки під час виконання робіт з підвищеною небезпекою (тільки ч. 1 ст.272 КК України);

47 - порушення правил, що стосуються безпечного використання промислової продукції або безпечної експлуатації будівель і споруд (тільки ч.1 ст.275 КК України);

48 - порушення правил безпеки руху або експлуатації залізничного, водного чи повітряного транспорту (тільки ч.1 ст.276 КК України);
49 - блокування транспортних комунікацій, а також захоплення транспортного підприємства (тільки ч.1 ст.279 КК України);

50- примушування працівника транспорту до невиконання своїх службових обов'язків (тільки ч.1 ст.280 КК України);

51- порушення правил повітряних польотів (тільки ч.1 ст.281 КК України);

52 - порушення правил використання повітряного простору (тільки ч.1 ст.282 КК України);

53 - самовільне без нагальної потреби зупинення поїзда (тільки ч.1 ст.283 КК України);

54 - ненадання допомоги судну та особам, що зазнали лиха (ст.284 КК України);

55 - неповідомлення капітаном назви свого судна при зіткненні суден (ст.285 КК України);

56 - керування транспортними засобами в стані алкогольного, наркотичного чи іншого сп'яніння або під впливом лікарських препаратів, що знижують увагу та швидкість реакції (ст.286-1 КК України);

57 - знищення, підробка або заміна номерів вузлів та агрегатів транспортного засобу (ст.290 КК України);

58 - групове порушення громадського порядку (ст.293 КК України);

59 - заклики до вчинення дій, що загрожують громадському порядку (ст.295 КК України);

60 - хуліганство (тільки ч.1 ст.296 КК України);

61 - незаконне проведення пошукових робіт на об’єкті археологічної спадщини, знищення, руйнування або пошкодження об’єктів культурної спадщини (тільки ч.1 ст.298 КК України);

62 - знищення, пошкодження або приховування документів чи унікальних документів Національного архівного фонду (тільки ч.1 ст.298-1 КК України);

63 - жорстоке поводження 3 тваринами (тільки ч.1 ст.299 КК України);

64 - створення або утримання місць розпусти і звідництво (тільки ч. 1 ст.302 КК України);

65 - незаконне виробництво, виготовлення, придбання, зберігання, перевезен- 


\section{Кримінальне право, кримінальний процес та криміналістика}

ня чи пересилання наркотичних засобів, психотропних речовин або їх аналогів без мети збуту (тільки ч.1 ст.309 КК України);

66 - посів або вирощування снотворного маку чи конопель (тільки ч.1 ст.310 КК України);

67 - незаконне виробництво, виготовлення, придбання, зберігання, перевезення чи пересилання прекурсорів (тільки ч.1 ст.311 КК Укранїни);

68 - незаконна видача рецепта на право придбання наркотичних засобів або психотропних речовин (тільки ч.1 ст.319 КК України);

69 - спонукання неповнолітніх до застосування допінгу (тільки ч.1 ст.323 КК України);

70 - ухилення від призову на строкову військову службу, військову службу за призовом осіб офіцерського складу (ст.335 КК України);

71 - ухилення від військового обліку або спеціальних зборів (ст.337 КК України);

72 - незаконне підняття Державного Прапора України на річковому або морському судні (ст.339 КК України);

73 - опір представникові влади, працівникові правоохоронного органу, державному виконавцю, приватному виконавцю, члену громадського формування 3 охорони громадського порядку і державного кордону або військовослужбовцеві, уповноваженій особі Фонду гарантування вкладів фізичних осіб (тільки ч.1 ст.342 КК України);

74 - втручання в діяльність працівника правоохоронного органу, судового експерта, працівника державної виконавчої служби, приватного виконавця (ст.343 КК України);

75 - погроза або насильство щодо службової особи чи громадянина, який виконує громадський обов'язок (тільки ч.1 ст.350 КК України);

76 - перешкоджання діяльності народного депутата України та депутата місцевої ради (ст.351 КК України);

77 - перешкоджання діяльності Рахункової палати, члена Рахункової палати (ст.351-1 КК України);
78 - перешкоджання діяльності Вищої ради правосуддя, Вищої кваліфікаційної комісії суддів України (ст.351-2 КК України);

79 - самовільне присвоєння владних повноважень або звання службової особи (тільки ч.1 ст.353 КК України);

80 - примушування до виконання чи невиконання цивільно-правових зобов'язань (тільки ч.1 ст.355 КК України);

81 - самоправство (ст.356 КК України);

82 - викрадення, привласнення, вимагання документів, штампів, печаток, заволодіння ними шляхом шахрайства чи зловживання службовим становищем або їх пошкодження (тільки ч.1 ст.357 КК України);

83 - підроблення документів, печаток, штампів та бланків, збут чи використання підроблених документів, печаток, штампів (тільки ч. 1, 2, 4 ст.358 КК України);

84 - умисне пошкодження або руйнування телекомунікаційної мережі (тільки ч. 1 ст.360 КК України);

85 - завідомо незаконні затримання, привід, домашній арешт або тримання під вартою (тільки ч.1 ст.371 КК України);

86 - розголошення відомостей про заходи безпеки щодо особи, взятої під захист (тільки ч.1 ст.381 КК України);

87 - введення в оману суду або іншого уповноваженого органу (тільки ч.1 ст.384 КК України);

88 - відмова свідка від давання показань або відмова експерта чи перекладача від виконання покладених на них обов'язків (ст.385 КК України);

89 - перешкоджання з'явленню свідка, потерпілого, експерта, примушування їх до відмови від давання показань чи висновку (ст.386 КК України);

90 - розголошення даних оперативнорозшукової діяльності, досудового розслідування (ст.387 КК України);

91 - ухилення від покарання, не пов'язаного з позбавленням волі (ст.389 КК України);

92 - умисне невиконання угоди про примирення або про визнання винуватості (ст.389-1 КК України); 
93 - невиконання обмежувальних заходів, обмежувальних приписів або непроходження програми для кривдників (ст.390-1 КК України);

94 - порушення правил адміністративного нагляду (ст.395 КК України);

95 - втручання в діяльність захисника чи представника особи (ст.397 КК України);

96 - представництво в суді без повноважень (ст.400-1 КК України);

97 - необережне знищення або пошкодження військового майна (тільки ч.1 ст.412 КК України);

98 - незаконне використання символіки Червоного Хреста, Червоного Півмісяця, Червоного Кристала (ст.445 КК України).

Кримінальні проступки займають особливе місце в кримінальному законодавстві в силу своєї поширеності. Серед загальної кількості розслідування злочинів тяжкі або особливо тяжкі складають $25 \%$, а злочини невеликої тяжкості - майже $50 \%$. $^{3}$

Кримінальний проступок - це передусім конкретна поведінка особи, іiі діяння, дії, або бездіяльність. Погляди людини, особисті думки, людські якості, законом не караються. Кримінальним проступком є тільки вольове, свідоме діяння, яке виявляється в активній поведінці людини або в ії бездіяльності. Такими є умисне легке тілесне ушкодження (ч. 1,2 ст. 125 КК України ); побої та мордування (тільки ч. 1 ст. 126 КК України); незаконне розголошення лікарської таємниці (ст. 145 КК України); ухилення від сплати аліментів на утримання дітей (ст. 164 КК України); грубе порушення угоди про працю (ст.173 КК України); безгосподарське використання земель (ч.1 ст. 254 КК України); групове порушення громадського порядку (ст. 293 КК України); хуліганство (тільки ч. 1 ст. 296 КК України) та інші.

Підставою виокремлення злочинів, тобто їх кваліфікації, як зауважують Савченко А.В. i Кузнєцов B.В., є обставини, які мають існувати на момент початку кваліфікації що стосуються оцінки конкретного діяння.

\footnotetext{
${ }^{3}$ Роман Оксанич Інститут кримінальних проступків зелене світло? https://yur-gazeta.com/gazeta/pdfissues/ tab/contributors/?show $=19$ \&author $=2283$.
}

Відповідно для здійснення правильної кваліфікації злочинів потрібно дотримуватись певних підстав і передумов. Підставою передбачається, що суб'єкт, що здійснює кваліфікацію, посилається на щось, виходить із обставин, причин і умов, йому відомо щось, як достатня підстава для його діяльності ${ }^{4}$. Це ж саме повністю відноситься і до кваліфікації кримінальних проступків.

Виходячи із змістуч. 1 ст. 2 Кримінального кодексу України, що «підставою кримінальної відповідальності є вчинення особою суспільно небезпечного діяння», можна визначити, що фактичною обставиною кваліфікації кримінального проступку є конкретний життєвий випадок - суспільнонебезпечне діяння.

\section{Висновок}

Нормативною юридичною підставою для кваліфікації кримінального проступку є його склад, який передбачений у кримінальній нормі. Встановлюючи юридичний склад кримінального проступку, закон визнає певну поведінку особи протиправною, перетворюючи тим самим такий тип суспільно небезпечної поведінки на кримінальний проступок певного виду. Тільки юридичний склад кримінального проступку дає підстави в процесі застосування норм Кримінального кодексу дійти висновку, який конкретно кримінальний проступок вчинила особа.

Суспільна небезпечність кримінального проступку, як його оціночна якість, є різною і залежить від об'єкта посягання: посягання на причинення шкоди здоров'ю, загрози вбивством, проти власності, заклики до вчинення дій, що загрожують громадському порядку, тощо.

Оцінка суспільної небезпечності кримінального проступку залежить від:

- об'єкта посягання, його вагомості і значимості;

- шкоди, заподіяної кримінальним проступком;

- способу вчинення кримінального проступку;

- мотиву і мети вчинення.

\footnotetext{
${ }^{4}$ Савченко А.В., Кузнєцов В.В. Теорія кваліфікації
} злочинів. Київ: Алерта, 2013, ст.11 (320 ст.). 


\section{Кримінальне право, кримінальний процес та криміналістика}

Як і для злочину, для встановлення кримінального проступку є загальнообов' язковими: а) суспільна небезпечність; б) кримінальна протиправність; в) винність та караність діяльності.

\section{Лiтература}

1. Савченко А.В., Кузнєцов В.В. Теорія кваліфікації злочинів. Київ: Алерта, 2013, ст.11 (320 ст.).

2. Закон України «Про внесення змін до деяких законодавчих актів України щодо спрощення досудового розслідування окремих категорій кримінальних правопорушень»//Відомості Верховної Ради України, 2017. - № 17, С. 71.

3. Кримінальний кодекс України//Вiдомості Верховної Ради України, 2001. -№ 25-26, С. 131 .

4. Оксанич Роман Інститут кримінальних проступків зелене світло? https://yur-gazeta.com/gazeta/pdfissues/tab/ contributors/?show $=19 \&$ cauthor $=2283$.
The article deals with the concepts and content of a criminal delict as a category of criminal law, describes the characteristics of criminal delicts, and provides a list of articles of the Criminal Code of Ukraine that provide for the composition of criminal delicts as criminal acts. It has been confirmed that the introduction of criminal delicts into Ukrainian legislation on criminal liability is one of the directions of the state criminal policy, which consists in humanizing criminal liability. It is shown that criminal delicts occupy a special place in the criminal legislation due to their prevalence in number and diverse impact on social relations.

It is argued that the regulatory legal basis for qualifying an unlawful act as a criminal delict is its composition, which is provided for in the criminal norm. As for the crime, in order to establish a criminal delict, the following are generally mandatory: a) public danger, b) criminal illegality c) guilt and punishment of the act.

The problem of introducing the institution of criminal delicts into national legislation remains open, despite a number of publications. Criteria for differentiation of types of criminal delicts from crimes, legal consequences of committed criminal delicts, counteraction of causes and conditions that contribute to the commission of delicts remain poorly researched.

Key words: criminal delict, legislation, criminal offence, infringement, composition of the delict, causal connection. 